University of Nebraska - Lincoln

DigitalCommons@University of Nebraska - Lincoln

To Improve the Academy

Professional and Organizational Development Network in Higher Education

1998

\title{
Teaching Large Classes: Unpacking the Problem and Responding Creatively
}

Elisa Carbone

James Greenberg

Follow this and additional works at: https://digitalcommons.unl.edu/podimproveacad

Part of the Higher Education Administration Commons

Carbone, Elisa and Greenberg, James, "Teaching Large Classes: Unpacking the Problem and Responding Creatively" (1998). To Improve the Academy. 399.

https://digitalcommons.unl.edu/podimproveacad/399

This Article is brought to you for free and open access by the Professional and Organizational Development Network in Higher Education at DigitalCommons@University of Nebraska - Lincoln. It has been accepted for inclusion in To Improve the Academy by an authorized administrator of DigitalCommons@University of Nebraska - Lincoln. 
Carbone, E., \& Greenberg, J. (1998). Teaching large classes: Unpacking the problem and responding creatively. In $\mathbf{M}$. Kaplan (Ed.), To Improve the Academy, Vol. 17 (pp. 311326). Stillwater, OK: New Forums Press and the Professional and Organizational Development Network in Higher Education. Key Words: educational objectives, faculty development, large group instruction, newsletters.

\section{Teaching Large Classes: Unpacking the Problem and Responding Creatively}

\section{Elisa Carbone}

\section{James Greenberg}

University of Maryland

Teaching large classes well is a continuing challenge for many universities. This article looks at one university's systematic approach to the problem. It describes how faculty and administrators from all over campus were involved in a Continuous Quality Improvement (CQI) process, how the problems were clearly defined and recommendations made, and how the solutions that emerged also involved faculty from across the curriculum.

How do we normally deal with a complex problem such as how to improve the teaching and learning in large classes? Too often-at least in our experience in academic settings-we refer it to an administrator, who can, at best, only deal with part of the problem, or we form a committee and talk it to death. This is perhaps especially true at large universities that have a tradition of decentralized academic responsibility and decision making. 
A few years ago, the University of Maryland decided to try a new approach. Under the growing influence of the principles and methodologies associated with Continuous Quality Improvement, the University's president charged each of his vice presidents with exploring a new problem solving model: identify a significant and persistent problem in your area of responsibility and use specific techniques to confront the problem comprehensively and identify solutions for action. Each team was given a strict 120 days to complete the task. The usual rules had clearly changed.

The Vice President for Academic Affairs and Provost chose the problem of large lecture classes as the target for Academic Affairs. There were many reasons for this, but among the most important was the perception - shared by a substantial proportion of students, faculty, and parents - that the large lecture class was a less than satisfactory learning experience for all concerned. After consultation with the Dean for Undergraduate Studies and other deans and colleagues, the Provost appointed a "cross-functional" team to take on this problem, and he named the Director of the Center for Teaching Excellence (CTE) as team leader. The makeup of the team was thought to be critical, and it included faculty - most of whom were teachers of large lecture classes-from arts and humanities, social science, and the "hard" sciences; importantly, the team also included key staff and administrators from counseling and learning assistance services, physical plant, and the honors program, as well as graduate and undergraduate students. Finally, a professional facilitator was appointed to help inform the team about appropriate processes and to contribute advice and assistance as needed.

\section{The Process}

\section{Problem Identification}

The team needed to look at the issue of large classes and identify what the problems really were. Given the variety of perspectives available on the team, we decided to go through an extensive brainstorming process to develop theories, projections, and experiencebased reflections on problems associated with large classes. By 
analyzing the results of the brainstorming, the team agreed that the problems could be clustered into five categories:

Mission. We concluded that we were faced with a mission that called for quality learning opportunities, commitment to active and interactive strategies, priority concern for developing critical thinking and high-level problem solving capabilities-and a large lecture class structure that appeared to work against all of those aims.

Students. There was consensus that students were part of the problem, partially because of poor general preparation as well as specific preparation for dealing with this different form and scope of a class, and partially because of an apparent lack of motivation.

Teachers. There was an equal consensus that teachers were part of the problem for two reasons. First, many faculty and TAs lack skills and preparation for teaching in this kind of environment. Second, large classes impose constraints upon such important factors as accessibility to students.

Administration and Management. While there was too much variation in terms of specifics to pinpoint the problem, the team agreed that the assignment of individuals to teach large classes, and the reward structure associated with such an important assignment, did not suggest that "the organization/institution" was making the kind of decisions or following the kind of policy that would help ensure high quality in large classes.

Physical Context. Lack of adequate and conducive spaces, properly outfitted to facilitate innovative and technology-aided teaching in large classes, was another component of the problem.

\section{Identifying Root Causes}

Next, we sought to determine the "root causes" for the problems we delineated and to decide on the relative importance of these root causes. In order to obtain a data-based perspective on our thinking, we initiated two surveys. One survey was aimed at the teachers of large classes (by our arbitrary definition, classes of 100 or more students), and the second survey was aimed at undergraduate students. (See Appendix A for the faculty survey and Appendix $\mathrm{C}$ for the student survey.) The faculty/teacher survey specified a number of elements- 
drawn from our brainstorming - under each of the problem categories, and it asked respondents (all were teaching large classes at the time or had taught such a class within the last two semesters) to tell us which "causes" they believed were most significant, i.e., most contributed to problems for teachers of large classes. The student survey asked respondents to rate the importance of various factors in regard to negative/positive experiences in large classes and to give overall opinions about their experience in large classes. We knew that the data produced by these surveys would help us in defining potential solutions and making recommendations for specific action.

\section{Considering the Data}

While our purpose didn't require the kind of rigorous and thorough sampling expected in a technically scientific study, we did obtain very useful data. The faculty/teachers who responded to the written survey ( 60 in number, out of 120 distributed) helped to clarify perceptions of root causes and priority concerns. (See Appendix B for complete results.) Listed below are the top five items (in priority order) that emerged from the survey.

- Conflict between large class format and learning goals

- Perceived lack of accessibility to students and personal contact

- Lack of student motivation and preparation for large class format

- Lack of reward structure for successful large class teaching

- Lack of accountability in student classroom performance

Comments also helped us understand some of the responses. For example:

- On the top "vote getter" regarding the conflict between format and learning goals, "This is the biggie! All of the activities one would wish to do are too time-consuming, expensive, and/or impossible with 300 students. With 2 TA's and 300 students one can only assign superficial writing assignments." 
- On the lack of accessibility and personalization, "I only know the troublemakers since no one else has any reason to see the professor. We should get more information about the students before the class."

- On the problem of student motivation, "The impersonal atmosphere of large classes gives students the impression no one cares how they perform and encourages them to skip class and studying."

- On the problem of reward system, "I have taught large classes . . for over 20 years. My experience has been that those efforts were seldom rewarded. My teaching evaluations from several hundred non-majors were placed into a departmental scale developed by faculty teaching a few dozen majors. I was always below the departmental average and yet, very few in the department could do what I do."

- On the problem of student accountability, "Very serious problem. Some policy on mandatory attendance should be put forth."

The student survey (given to a sample of about 100 students who served as a representative campus polling group) gave us an additional perspective. (See Appendix D for complete results). Based on responses from these students, the most important factors-in orderthat emerged were:

- Overall dissatisfaction with the quality of large class learning experience

- Lack of interaction with faculty (in and out of class)

- Lack of structure in lecture

- Lack of/poor discussion sections

- Inadequate contact with teaching assistants

- Inadequacy of classroom facilities and environment

- Lack of frequent testing/graded assignments 


\section{Responding to the Issues}

\section{Initial Responses}

The process of "unpacking the problem" and gathering and considering data gave rise to a variety of recommended solutions and creative responses. The solutions that the team recommended included both short-term and longer-term specifics, and some had cost implications. Among those which were implemented fairly quickly was the production of a Large Classes Handbook. This was written by CTE's Jennifer Robinson and was sent to each teacher of a class of 100 or more students. It contains tips and resources related to improving teaching in the large class environment. Other short-term responses were: a mandated self-study conducted by colleges of their policies and practices regarding the management and reward structure pertaining to large classes; the scheduling of a number of workshops targeted specifically to large class teaching issues; and the activation of a campus-wide facilities committee to consider and begin action on improving large class physical teaching environments.

\section{Continuing to Respond: The Large Classes Newsletter}

Over and above these efforts, we wanted to develop a special program that would best reach out to the entire group of $\mathbf{3 0 0}$ large classes faculty and make the most impact toward improving the teaching of large classes.

We had seen that one faculty development strategy that seemed to have great power to improve teaching was individual meetings with faculty members who asked for help. It would, of course, not be practical to meet with each of the 300 large classes teachers individually, and not all of them were asking for help. But it did seem prudent to let large classes faculty know that we were taking a special interest in their concerns; we were educating ourselves about effective solutions to their problems; and we were available to share these solutions.

Workshops were another possible solution. As stated earlier, we decided to add several workshops each semester directed at teachers of large classes. But, past experience had shown that only a small percentage of the 300 large classes faculty members would attend the 
workshops, and while those who attended would no doubt gain many new ideas and teaching strategies, there might still be over 200 teachers who would never attend a single workshop. What could we do to interest these non-attenders in exploring new approaches to their teaching of large classes?

Through workshops, consultations, and observations we had discovered that there were many large classes faculty who were doing marvelous things in their lecture halls. There were those who had learned how to personalize their classes of 500 students, who had learned to manage student behavior, make their large classes active, and do wonders with their teaching assistants. How could we give validation to these teachers for their excellent ideas and maybe even disseminate these ideas to other faculty?

After much brainstorming and mulling, we came up with an idea that would at least begin to answer each of these questions. In order to glean the strategies and ideas being used by successful teachers, we would visit their classes and interview them. In addition, in order to discover more good teaching practices and ideas, we would hold brainstorming sessions with interested large classes faculty about several of the more heated topics, such as assessment in large classes and managing student behavior in large classes. In this way, we would find out what the many years of experience, trial and error, and success had taught the large classes faculty at our university.

The information gained from these visits, interviews, and brainstorming sessions would be compiled into articles, and the articles disseminated through a newsletter that would reach each of the large classes faculty. Then, in the privacy of their own office, at their own pace, teachers could read about what their colleagues were doing and consider adding a new strategy or two to their own teaching.

The newsletter was titled, The Large Classes Newsletter. In a friendly four page format it included a letter from Jim and Elisa, a short article focused on a particular topic of concern to large classes faculty and students, a cartoon focused on the same topic (a freshman journalism major produced a wonderful cartoon each month), letters to the editor or short pieces written by faculty when we had them, and an occasional book review when a new book on large classes became available in the CTE library. Initial topics covered in the newsletter 
were derived from the issues that were brought up during the CQI process. For example, in response to the perceived lack of accessibility/interaction with faculty, we put out an issue on "Personalizing the Large Class." Complaints about poor discussion sections were addressed in "Working Effectively with Teaching Assistants." Solutions to the lack of frequent testing/graded assignments were suggested in "Assessment and Feedback in Large Classes: Frequent Assessment without Frequent Headaches." The lack of accountability in student classroom performance was treated in "Classroom Management in Large Classes," with suggestions for ways to take roll, ways to encourage students to come to class, and ways to minimize disruptions. In addition to information from the literature, each article described the teaching practices of several faculty members from different disciplines and included quotes from interviews with them. Full names were used, as were photographs when space permitted. It was a very personal and informal approach, as one of our goals was to create a sense of community among the large classes faculty scattered across the campus. We also hoped that the personal approach would be a non-threatening way to interest those "non-attenders of workshops" in new teaching ideas for their classrooms. The newsletter communicated our concern, our growing knowledge about good teaching practices in large classes, and our availability to discuss faculty concerns. It was delivered to the mail box of every single teacher of a large class on campus, and within two and a half years it had profiled 42 of these teachers.

The newsletter did help create a sense of community. Dialog was begun through letters to the editor, and often issues from a newsletter would be discussed at one of the workshops planned for large classes faculty. We sent out questionnaires asking faculty, "What question would you like to ask other teachers of large classes?" From the responses, we discovered several new areas of concern and planned new articles for the newsletter. Another questionnaire provided us with very positive faculty feedback. They especially appreciated hearing about what their colleagues were doing and learning specific strategies that were classroom tested.

An excellent way we found to get faculty involved was the use of informal brainstorming sessions. A flier was sent out to let all $\mathbf{3 0 0}$ 
faculty know we'd be meeting for two hours to discuss, for example, using e-mail with large numbers of students; dealing with the way students in large classes arrive late, leave early, and read the newspaper in between; or avoiding headaches when trying to assess the work of 500 students. No one had to be an expert on the topic to attend these sessions, only interested. We began each session by simply compiling all of the problems we'd come up against in the area being discussed. While the group threw out issues and concerns, one of the participants wrote each item on a large piece of newsprint so we'd have a record when it came time to brainstorm solutions.

When the listing of problems slowed down, we moved to sharing the things we' $d$ tried in our own large classes that had been successful. There were no "right" answers, only descriptions of how things had worked. These ideas were built on by other participants, and all of it was recorded on a new piece of newsprint. By the time we left, we had a long list of possible solutions for each of the previously listed problems. In addition, everyone had been able to "vent" some of their frustration about a difficult issue and had been able to feel that they were not alone in their angst. An article was written from each of these brainstorming sessions, and the names of all who attended were included in the newsletter.

\section{Further Validation}

Happily, the articles from The Large Classes Newsletter have been organized, expertly edited, indexed, and published by Sage Publications in a book entitled Teaching Large Classes: Tools and Strategies (1998). We celebrate the making public of a project that has involved so many people from so many departments. For faculty, the publication confirms the value of the teaching practices profiled in the articles. For those of us who worked on the large classes project as it took shape, the book is additional evidence that our efforts were well spent.

\section{Conclusion}

Clearly, a complex issue such as the quality of large classes does not lend itself to single or simple solutions. The comprehensive 
process through which we studied the issue on this campus, and the variety of actual and potential solutions that emerged, suggest a viable model. Although such a model could work on any campus, we do realize that the range of problems raised by large courses goes beyond the strategies we have developed so far. Therefore, we will continue to try new approaches, vary our responses to the problems, and experiment with new solutions.

\author{
Contacts: \\ Jim Greenberg and Elisa Carbone \\ Center for Teaching Excellence \\ 2130 Mitchell Building \\ University of Maryland \\ College Park, MD 20742 \\ (301) 405-9368 \\ (301) 314-9896 FAX \\ jg55@umail.umd.edu \\ (http://www.inform.umd.edu/CTE/)
}

James D. Greenberg, $\mathrm{PhD}$, is founding Director of both the University of Maryland's Center for Teaching Excellence and the College of Education Honors Program. He is Coordinator of Teacher Education Development in the College of Education and has been a faculty member and administrator at the University for over 25 years. He has published on a variety of educational topics and has made numerous presentations of scholarly papers and workshops at the local, state, national, and international levels. He has served as a consultant to schools and school systems, colleges and universities, federally- and corporate-sponsored projects, and both U.S. agencies and universities in several foreign countries. He is the recipient of the College of Education's1997 Vernon E. Anderson Distinguished Faculty Award.

Elisa Carbone is Coordinator of the Large Classes Project for the Center for Teaching Excellence at the University of Maryland. She is an adjunct faculty member in Speech Communication at the University of Maryland University College, where she was nominated for the Excellence in Teaching Award. She is the author of the book Teaching Large Classes: Tools and Strategies (Sage Publications, 1998) as well as several novels for young people. She conducts workshops nationwide on such topics as active learning, lecturing skills, and teaching large classes. 


\section{Appendix A \\ Faculty Survey}

Directions: Below is a summary of what our committee on large classes has surmised-to this point-about categories of problems pertaining to large classes and perceived causes underlying each problem category. Pleae give us your opinion of which causes are most important by circling those which you believe stand out significantly. We really want to know why you identified these causes (or any others you believe we left out) and hope you will write a brief comment in the space provided below. Fold and staple this sheet, and return it to the address on the back. If you prefer to respond by electronic mail, note the numbers of the most important items below (+ your comment) and sent to: jg55@umail.umd.edu Many thanks!

Teaching Mission Students $\quad$ Faculty Teachers Admin.Management Physical Context

1. Lack of consistency and consensus on goals; e.g., content coverage vs. understanding and critical thinking

\section{Lack of consistency} between teaching-learning goals and large class format; e.g., difficulty of including writing assignments, experiments, student interaction, etc.

3. Lack of regular review of course goals, content, and intended audience

\section{Lack of motivation}

7. Lack of preparation for teaching

8. Lack of skills

5. Lack of preparation for large 9. Lack of resources classes environmenttransition from high school to new format and responsibility level

10. Lack of motivation for teaching large classes

11. Lack of accessibility to students (perceived); lack of personalization, contact 12. Lack of coordination and oversight of what TAs do

6. Lack of skills, intelligence

\section{TAS}

13. Lack of preparation for teaching

14. Lack of skills (language and/or teaching skills)
15. Lack of systematic process for matching best teachers for large classes with those assignments

16. Lack of effective evaluation

17. Lack of reward and recognition system re: success with large classes

18. Lack of course structure which makes students accountable for class attendance

20. Lack of adequate spaceflexible space

21. Lack of teaching aids (e.g., $\mathrm{a}-\mathrm{v})$ in some classrooms

22. Lack of top-notch computer access and network system
19. Lack of appropriate match between TAs and faculty 


\section{Appendix B}

\section{Faculty Survey Results}

Quantitative Analysis

Total number of respondents: 60

Comment Number and Number of Respondents:

$\begin{array}{rr}1 . & 2 \\ 2 . & 30 \\ 3 . & 0 \\ 4 . & 26 \\ 5 . & 18 \\ 6 . & 5 \\ 7 . & 5 \\ 8 . & 3 \\ 9 . & 5 \\ 10 . & 9 \\ 11 . & 28 \\ 12 . & 8 \\ 13 . & 15 \\ 14 . & 10 \\ 15 . & 5 \\ 16 . & 4 \\ 17 . & 22 \\ 18 . & 17 \\ 19 . & 3 \\ 20 . & 8 \\ 21 . & 14 \\ 22 . & 6\end{array}$




\section{Appendix C}

\section{Student Survey}

1. How do you define a large class? 51-100 students 1-30 student 31-50 students more than 100 students

2. Since enrolled at UMCP, how many large classes have you taken? none 1-5 6-10 11-15 more than 16

Use the following scale to represent your views on questions 3 STRONGLY DISAGREE NEUTRAL STRONGLY AGREE 1 3

3. Please take a few moments and tell us your feelings about the following important issues related to large classes:

I believe I have taken too many large classes.

I am satisfied with the quality of instruction in large classes.

The amount of interaction with the professor/instructor during the class is adequate.

The professor/instructor is approachable outside of class. The amount of interaction with my fellow students during large classes is adequate.

I am actively involved in learning in large classes through writing assignments, asking questions, homework, quizzes, projects, laboratories, discussions, etc.

I would prefer to take a small class taught by a graduate student versus a large class taught by a member of the faculty. I "cut" large classes more frequently than small classes. The size of the class does not affect my ability to learn. I prefer to buy lecture notes rather than attend large classes. Frequently testing (e.g., quizzes, graded assignments) helps me keep up in class. 
Use the following scale to represent your views on question 4. VERY NEGATIVE IMPACT — NEUTRAL IMPACT — VERY POSITIVE IMPACT

4. Please note the type of impact the following have on your experiences in large classes:

Teaching skills of the professor/instructor
Amount of content covered by the course
Ability to be anonymous
Structured lectures
Discussion sections
Amount of interaction with other students during class
Use of overhead projectors
Use of video technology
Use of demonstrations
Use of guest speakers
Coordination between lecture and discussion section
Comfort in asking questions during class
Amount of contact with the professor/instructor
Amount of contact with the teaching assistant
Possible exchange of information/questions with the
professor/instructor through electronic mail
Classroom facilities (sight lines in the room, visibility
of the chalk board, quality of seating, a/v equipment and
sound systems, etc.)
Physical surroundings (room temperature, noise, areas to
wait/study prior to class, etc.)

5. What ideas do you have to improve the educational experiences in large classes? 


\section{Appendix D}

\begin{tabular}{|c|c|c|c|c|c|}
\hline \multicolumn{6}{|c|}{ Results of Student Survey } \\
\hline \multicolumn{2}{|c|}{$\begin{array}{l}\text { Strongly } \\
\text { Disagree } \\
1\end{array}$} & \multirow{2}{*}{\begin{tabular}{|c|} 
Neutral \\
3 \\
3 \\
\end{tabular}} & \multicolumn{2}{|c|}{$\begin{array}{l}\text { Strongly } \\
\text { Agree } \\
5\end{array}$} & \multirow[b]{2}{*}{ Question \#3 Issues related to large classes. } \\
\hline 1 & 2 & & 4 & 5 & \\
\hline $20 \%$ & $13 \%$ & $35 \%$ & $9 \%$ & $24 \%$ & I believe I have taken too many large classes. \\
\hline $19 \%$ & $20 \%$ & $33 \%$ & $24 \%$ & $5 \%$ & $\begin{array}{l}\text { I am satisfied with the quality of instruction in } \\
\text { large classes. }\end{array}$ \\
\hline $25 \%$ & $29 \%$ & $28 \%$ & $11 \%$ & $8 \%$ & $\begin{array}{l}\text { The amount of interaction with the } \\
\text { professor/instructor during the class is adequate. }\end{array}$ \\
\hline $8 \%$ & $19 \%$ & $35 \%$ & $29 \%$ & $9 \%$ & $\begin{array}{l}\text { The professor/instructor is approachable outside } \\
\text { of class. }\end{array}$ \\
\hline $20 \%$ & $22 \%$ & $25 \%$ & $18 \%$ & $15 \%$ & $\begin{array}{l}\text { The amount of interaction with my fellow } \\
\text { students during large classes is adequate. }\end{array}$ \\
\hline $19 \%$ & $14 \%$ & $27 \%$ & $32 \%$ & $9 \%$ & $\begin{array}{l}\text { I am actively involved in learning in large } \\
\text { classes through writing assignments, asking } \\
\text { questions, homework, quizzes, projects, } \\
\text { laboratories, discussions, etc. }\end{array}$ \\
\hline $11 \%$ & $22 \%$ & $27 \%$ & $20 \%$ & $20 \%$ & $\begin{array}{l}\text { I would prefer to take a small class taught by a } \\
\text { graduate student versus a large class taught by } \\
\text { a member of the faculty. }\end{array}$ \\
\hline $13 \%$ & $4 \%$ & $22 \%$ & $13 \%$ & $49 \%$ & $\begin{array}{l}\text { I "cut" large classes more frequently than small } \\
\text { classes. }\end{array}$ \\
\hline $25 \%$ & $28 \%$ & $22 \%$ & $11 \%$ & $14 \%$ & $\begin{array}{l}\text { The size of the class does not affect my ability to } \\
\text { learn. }\end{array}$ \\
\hline $41 \%$ & $15 \%$ & $22 \%$ & $11 \%$ & $11 \%$ & $\begin{array}{l}\text { I prefer to buy lecture notes rather than attend } \\
\text { large classes. }\end{array}$ \\
\hline $9 \%$ & $4 \%$ & $24 \%$ & $29 \%$ & $34 \%$ & $\begin{array}{l}\text { Frequent testing (e.g., quizzes, graded } \\
\text { assignments) helps me keep up in class. }\end{array}$ \\
\hline
\end{tabular}




\begin{tabular}{|c|c|c|c|c|l|}
\hline $\begin{array}{c}\text { Very Negative } \\
\text { Impact } \\
1\end{array}$ & $\begin{array}{c}\text { Neutral } \\
\text { Impact } \\
3\end{array}$ & \multicolumn{2}{|c|}{$\begin{array}{c}\text { Very Positive } \\
\text { Impact }\end{array}$} & \\
\hline 1 & 2 & 3 & 4 & 5 & $\begin{array}{l}\text { Question \#4. The type of impact the following } \\
\text { have on your experiences in large classes: }\end{array}$ \\
\hline $5 \%$ & $10 \%$ & $36 \%$ & $17 \%$ & $32 \%$ & Teaching skills of the professor/instructor \\
\hline $9 \%$ & $14 \%$ & $37 \%$ & $23 \%$ & $17 \%$ & Amount of content covered by the course \\
\hline $16 \%$ & $13 \%$ & $41 \%$ & $19 \%$ & $11 \%$ & Ability to be anonymous \\
\hline $6 \%$ & $12 \%$ & $26 \%$ & $27 \%$ & $28 \%$ & Structured lectures \\
\hline $2 \%$ & $15 \%$ & $19 \%$ & $23 \%$ & $41 \%$ & Discussion sections \\
\hline $9 \%$ & $20 \%$ & $42 \%$ & $12 \%$ & $17 \%$ & $\begin{array}{l}\text { Amount of interaction with other students during } \\
\text { class }\end{array}$ \\
\hline $11 \%$ & $12 \%$ & $48 \%$ & $16 \%$ & $12 \%$ & Use of overhead projectors \\
\hline $6 \%$ & $15 \%$ & $43 \%$ & $20 \%$ & $16 \%$ & Use of video technology \\
\hline $0 \%$ & $12 \%$ & $24 \%$ & $31 \%$ & $33 \%$ & Use of demonstrations \\
\hline $6 \%$ & $6 \%$ & $48 \%$ & $22 \%$ & $18 \%$ & Use of guest speakers \\
\hline $0 \%$ & $14 \%$ & $22 \%$ & $35 \%$ & $29 \%$ & $\begin{array}{l}\text { Coordination between lecture and discussion } \\
\text { section }\end{array}$ \\
\hline $21 \%$ & $12 \%$ & $25 \%$ & $21 \%$ & $22 \%$ & Comfort in asking questions during class \\
\hline $23 \%$ & $14 \%$ & $22 \%$ & $21 \%$ & $19 \%$ & Amount of contact with the professor/instructor \\
\hline $9 \%$ & $9 \%$ & $30 \%$ & $27 \%$ & $25 \%$ & Amount of contact with the teaching assistant \\
\hline $13 \%$ & $3 \%$ & $49 \%$ & $16 \%$ & $19 \%$ & $\begin{array}{l}\text { Possible exchange of information/questions with } \\
\text { the professor/instructor through electronic mail }\end{array}$ \\
\hline $13 \%$ & $16 \%$ & $25 \%$ & $23 \%$ & $23 \%$ & $\begin{array}{l}\text { Classroom facilities (sight lines in the room, } \\
\text { visibility of the chalk board, quality of seating, } \\
\text { a/v equipment and sound systems, etc.) }\end{array}$ \\
\hline $11 \%$ & $18 \%$ & $26 \%$ & $20 \%$ & $25 \%$ & $\begin{array}{l}\text { Physical surroundings (room temperature, } \\
\text { noise, areas to wait/study prior to class, etc.) }\end{array}$ \\
\hline
\end{tabular}

